\title{
Translation Shift in George Orwell's Animal Farm as Assessing Readability in Indonesian Translation
}

\author{
Marini Saraswati \\ Universitas Negeri Surabaya \\ Surabaya, Indonesia \\ marinisaraswati@mhs.unesa.ac.id
}

\author{
Adam Damanhuri \\ Universitas Negeri Surabaya \\ Surabaya, Indonesia \\ adamdamanhuri@unesa.ac.id
}

\begin{abstract}
This study aims to identify what types of translation shift that is used in the Indonesian translation novel and how it can assess the readability of the target language text. Recognizing the translation strategies also can affect the use of shifting in the target language. Most of the researchers evaluated readability with a number by calculating a formula. Meanwhile, in this study, assessing readability used qualitative research by describing the contextual knowledge of the reader who is also the researcher. The contextual (background) knowledge of the reader can be an assessment of readability by showing a correlation between the text and context of the target language text. As a result of this study, the researcher found 89 shifting in the form of a particular sentence. The shifting is divided into four types, level shift, structure shift, unit shift, and class shift. In these different shiftings, the translator still does not change the message of the source language text and uses some strategies that are used to imply shifting. There are two types of strategy that is used in the novel, syntactic and semantic strategy. Through translation shifts, readability can be evaluated based on the contextual knowledge of the reader. The context of the reader can be a history of a particular country or a habitual activity that has become a value of life. Therefore, translation is not only assessed by calculating a formula, but it can be evaluated through the prior knowledge of the reader.
\end{abstract}

Keywords-translation; shifting; readability

\section{INTRODUCTION}

Shifting often occurs in a particular translation to get the equal meaning of the source language. When translating the written texts, translators must deliver the message of the source language into the target language. It means that translation transmits the meaning or the message into the target language by equal words, phrases, and sentences that have similar meaning with the source language. It occurs because both languages have their own rules and characteristics. However, the translation needs shifting to get the equivalence of meaning and the ease of reading.

The equivalence of the message is an important part of the translation. Its equivalences depend on language use and the context of the target language such as the aspects of human beings. Therefore, the translators should understand the diction, grammatical rule, and the context between SL and TL firstly before transmitting the language. Through shifting, translators transfer the meaning or the message of SL depends on the context of TL. The context of the text influences the shifting of words, phrases, and sentences. It also determines the readability of the text so that the reader can easy to read and understanding the message of the text. The study of readability can be a property to help the writer communicates with the reader in a written text. On a theoretical level stated by Bailin and Grafstein [2], readability is relevant to many areas such as applied linguistics, text and discourse theory, and natural language processing. According to Aukerman [1], readability is a wide term used to cover various aspects of written materials that determine the reading difficulty of a printed page. It concerns to evaluate the written materials what the aspects of readability are. Based on the problem that is explained above, there are three discussions that are identified, (1) kinds of translation shifts that are found in George Orwell's Animal Farm, (2) translation strategy that is applied in the shifting, and (3) how the readability of the translation shift based on the contextual (background) knowledge.

Referred to the discussion, the purpose of this study are (1) to find out the kinds of translation shift in George Orwell's Animal Farm that is translated from English to Bahasa Indonesia, (2) to identify the strategy of translation shift that is applied, and (3) to identify the readability of the translation shift according to the contextual (background) knowledge. Some theories are used to investigate this study. According to Catford [6], there are two major types of 'shift' which include level shifts and category shifts. Level shifts occur in the level of grammar to lexis or vice versa between SL and TL. This kind of shift is known as level-shifts in translation and such shifts are quite common. SL item at one linguistic level has a TL translation equivalent at a different level. On the other hand, category shifts relate to the term 'rank-bound' translation only to refer to special cases where equivalence is deliberately limited to rank below the sentence. In unbounded, then, translation equivalence may occur between sentences, clauses, groups, words and rarely morphemes. Changes of rank (unit shifts) are not the only changes of this type that occur in translation, but there are also changes of structure, changes of class, changes of the term in the system, etc. It is divided into four types namely structure shifts, class shifts, unit shifts, and intra-system shifts. For the second research question, this study uses the types of translation strategies of Chesterman [12] and any other theories, but they have been simplified by Sugeng Hariyanto and Zuchridin Suryawinata [7] in their book entitled Translation: Bahasan Teori dan Penuntun Praktis Penerjemahan. According to them, there are three basic strategies of translation, syntactic strategy, semantic strategy, 
and pragmatic strategy. Syntactic strategy relates to the structure or form of the written texts that changes between SL and TL to get the ease of reading and understanding. It consists of four strategies, addition, subtraction, transposition, and modulation. In the second one, the semantic strategy considers the meaning of the text. It is operated at the level of words, phrases and clauses or sentences. It consists of six strategies, borrowing, cultural equivalent, descriptive equivalent and componential analysis, synonymy, official translation, and depreciation and expansion. The last one, pragmatic strategy can change the message because the changing can happen that is greater than the syntactic and semantic strategies. This strategy is often used by considering the overall message of the text or part of the text. There are several types in this strategy such as changing the clarity of meaning, information change (adding or reducing information), interpersonal change, illocutionary change, information structure change, partial translation, visibility change, trans editing, and adaptation. Readability is a term to examine a discourse dealing with the ease of reading. According to Alan Bailin and Ann Grafstein [2], readability is a wide term used in many fields of human life, such as education, medical, business, and any other fields. This is needed to do a variety of tasks, such as choosing the reading materials, teaching writing and communication skills, and some other tasks. It means that the readability is needed in proposing the ease of reading and understanding the topic or the issue of written texts.

Actually, most people prefer the materials which are more interesting and understanding of them. Mr. Bhagoliwal (Sinha, Sharma, Dasgupta, and Basu) [10] stated that the most commonly emphasized aspects of readability are legibility, interest, ease of reading and understanding. These three factors are of course interrelated. It means that the reader will choose the book that is familiar and interested for them. It depends upon many other things such as the content of the subject matter, its theme, illustrations, clarity, and color of printing, and the total gets up of the book. In the same way, ease of the reading depends on the vocabulary that is included in the language for presenting the matter of its sentence structure. In addition to this, the format as like good paragraphing, bold type and summaries may affect the ease of understanding. The ease of understanding and interest also depend upon legibility.

Alan Bailin and Ann Grafstein [2] argued that the properties of texts and contexts can affect comprehension which can construct the theory of readability. They suggested that there are three basic concepts to understand readability related to textual comprehension. Firstly, contextual (background) knowledge refers to any information of written texts to make inferences that are needed the reader to understand it. It includes the prior knowledge and assumptions of words meaning that readers bring to a text and also the inferences from the text that readers use in interpreting the following parts of the text. Secondly, linking refers to the connection of units of information on the words, sentences, even the discourse level. It also relates to the comprehension of texts and the syntactic units of information to link together so that the reader will understand the topic or the issue of written texts. Lastly, ambiguity relates to the words, phrases, and sentences that have more than one meaning that can influence the comprehension of texts. It occurs because of the ambiguous grammatical structure and the reference of a word or phrase is unclear. However, this study chooses contextual or background knowledge to assess the readability of the target language. It focuses on the context of the texts which have been adjusted to the culture of the country where the target language is.

\section{A. Definition of Translation}

The translation is a craft consisting of the attempt to replace a written message and/or statement in one language by the same message and/or statement in another language, Newmark [13]. So, translation can be told as a process of transferring the messages written from one language to another language. Another way Brislin [4] also said that translation is one of the general technical terms which turn on transferring mind, idea or concept from the source language to target language.

Kridalaksana defines the translation as displacement of instruction from the source language to the target language, firstly to reveal the message, and then the language style [16] while Munday [17] said that translation is an act of communication that attempts to relay, across cultural linguistics boundaries, another act of communication that may have been intended for different purposes and different readers.

Several definitions above reveal that translation is the process of transferring messages or meaning of the text from one language to another language. So, there is no message or meaning of the text left behind, all of them transferred into the target language.

\section{B. Strategy or Technique of Translation}

In the process of translating, it needs to understand techniques of translation as the instrument to transfer the source text into the target text. To understand the technique itself, Molina \& Albir [3] said that in the process of translating has strategies and the process of thinking how to shift messages of the source text into the target text. Thus, named techniques of translation is as a process of making a decision to transfer the message of the text.

These are various of techniques found by Molina \& Albir, [3]: (1) adaptation, (2) amplification, (3) calque, (4) compensation, (5) description, (6) discursive creation, (7) established equivalent, (8) generalization, (9) borrowing: a. pure borrowing, b. scientific borrowing (10) amplification, (11) linguistic compression, (12) literal translation, (13) modulation, (14) particularization, (15) reduction, (16) substitution, (17) transposition, (18) variation. Those techniques of the translation will form a style and strategy of the translator in transferring the message of the text.

\section{METHOD}

The focus of this research is the words, phrases, and sentences in George Orwell's Animal Farm as the source language and the target language. The research questions related to the form of translation shift. The source language is from English while the target language is Indonesian. The data analysis of this research is taken by the structure of the text and also the context of the source language and the target language. This research provides a translation shift that occurs in the target 
language. This research does not use statistics or numbers but uses sentences to explain the result of the research. This research applies the descriptive qualitative method to provide data analysis. According to Bryman and Bell [5], qualitative research is a strategy of research showing the relationship between theory and research. Another definition of qualitative research comes from Fraenkel \& Wallen [8]. They said that qualitative research is a research with a natural form that attitude and behavior can occur. It focuses on participants' perceptions and experiences, and the way they make sense of their lives. The data from qualitative research use the descriptive form of writing. The data are reported in words, phrases, sentences or even pictures, rather than in numbers. This research uses the qualitative approach because the subject of the research is a novel which is the text form. The source language is a novel titled Animal Farm that was written by George Orwell using English while the target language is a translation of the novel using Indonesian. Using a qualitative method, the researcher is easier to explain the result of this research.

The object of this study is a novel written by George Orwell entitled Animal Farm. It focuses on the structure or form of the text in the source and target language. The source language comes from English whereas the target language is Indonesian. The researcher analyzes this subject of the study through the story itself. All of the chapters of the story will be analyzed and find the answers to the research questions. The data of this study are the words, phrases, or sentences which are taken from a novel written by George Orwell under titled Animal Farm. The source of data is the forms or structures of the words, phrases, or sentences in every part of the text which contain linguistic untranslatability. According to Marshall [15], there are four techniques for collecting data in qualitative researches. There are participating in the setting, observing directly, interviewing indepth, and analyzing documents and materials culture. This study uses analysis documents and materials culture to collect the data because the data is collecting by analyzes the text of the novel.

\section{RESULTS AND DISCUSSION}

The data have been taken from the original novel of George Orwell's Animal Farm and the Indonesian version of it. This study found 88 data of shifting, but in this chapter, there are 11 data that will be explained, as follows.

\section{A. Level Shift}

After reading the novel, this study found 9 data that is included as a level shift. The researcher will explain two examples that represent the level shift data which be categorized into grammar to lexis.

\section{1) Grammar to lexis}

An example of this is included as 'grammar to lexis' because there is a changing from the perfective grammar of SL text into lexis by adding a word telah or sudah in a particular sentence.

TABLE I. THE EXAMPLE OF GRAMMAR TO LEXIS

\begin{tabular}{|c|c|}
\hline Grammar & Lexis \\
\hline
\end{tabular}

(1a) Now that the small field beyond the orchard had been set aside for barley,. . . (Ch. IX Page 43)

(1b) Sekarang, lapangan kecil di dekat kandang telah diperuntukkan buat tanaman selai.

In the example above, the SL text uses perfective grammar to indicate the past time. The sentence (1a) uses past perfect tense with the structure 'had+V3' in the passive form. In sentence (1b), the word 'had' changes into the word telah that indicates the work has already done. It shows that the perfective grammar as like as had+V3 changes into the lexis level using the word telah. It commonly occurs in the translation because of the differences in grammatical rules between the SL and TL.

\section{2) Category shift}

The category shift is divided into four types, structure shift, class shift, unit shift, and intra-system shift.

\section{a) Structure shift}

After reading the novel, there are 56 data that is included as a structure shift. The researcher will explain four examples that represent the data of structure shift which are categorized into three types, as follows.

\section{- $\quad$ Positive to negative}

The first category is changing from positive construction into negative construction. It can be showed through the form of a particular sentence.

TABLE II. ThE EXAMPLE of Positive to Negative

\begin{tabular}{|l|l|}
\hline \multicolumn{1}{|c|}{ Positive } & \multicolumn{1}{|c|}{ Negative } \\
\hline $\begin{array}{l}\text { (3a) It had beenagreed that they } \\
\text { should all meet in the big barn } \\
\text { as soon as Mr. Jones was } \\
\text { safelyout of the way. (Ch. I } \\
\text { Page 1) }\end{array}$ & $\begin{array}{l}\text { (3b) Sudah disepakati, mereka semua } \\
\text { hegitu tuan Jones sudah tidak } \\
\text { menampakkan diri. }\end{array}$ \\
\hline
\end{tabular}

Like the example above, the phrase 'was safely out of the way' becomes the negative phrase sudah tidak menampakkan diri. It represents the shifting between the SL and TL text when translating the text. It can be called as the structure shift because of the changing in the structure of the sentence from the positive to negative form.

- $\quad$ Negative to positive

In the second category, there is a shifting from the negative structure of SL text into the positive structure of TL text. It often occurs because both languages have their own characteristics.

TABLE III. THE EXAMPLE OF NEGATIVE TO POSITIVE

\begin{tabular}{|l|l|}
\hline \multicolumn{1}{|c|}{ Negative } & \multicolumn{1}{|c|}{ Positive } \\
\hline $\begin{array}{l}\text { (5a) Boxer could not get } \\
\text { beyond the letter D. }\end{array}$ & $\begin{array}{l}\text { (5b) Sedangkan kuda penarik kereta } \\
\text { lainnya-Boxer hanya mampu } \\
\text { menghapal huruf D. }\end{array}$ \\
\hline
\end{tabular}


The phrase 'could not get beyond the letter D' actually can be translated like this one, Boxer tidak dapat melampaui huruf $D$ without omitting the word 'not', but it changes into the positive construction in the TL text as like in the sentence 5b. Without the word 'not', the translator tries to clarify the subject of the sentence who only memorizes the letter $\mathrm{D}$ and translates as like this, hanya mampu menghapal huruf $D$. This positive level purposes to emphasize the subject. Therefore, there is a shift that occurs from the positive construction into the negative one.

\section{- Active to passive}

This category is changing from an active sentence into a passive sentence by looking at the structure of a particular sentence.

TABLE IV. THE EXAMPLE OF ACTIVE TO PASSIVE

\begin{tabular}{|l|l|}
\hline \multicolumn{1}{|c|}{ Active } & \multicolumn{1}{|c|}{ Passive } \\
\hline $\begin{array}{l}\text { (6a) The dogs had suddenly } \\
\text { caught sight of them, ... }\end{array}$ & $\begin{array}{l}\text { (6b) Kehadiran mereka tertangkap } \\
\text { oleh pandangan mata anjing-anjing, . } \\
\text {. }\end{array}$ \\
\hline
\end{tabular}

In this example above, it is also included the structure shift because there is a changing from the SL text into the TL text. The sentence (6a) of SL text is an active sentence while sentence (6b) of TL text is a passive sentence. In this case, the active sentence in the SL text changes into the passive sentence in the TL text. This changing can be known through the subject, the object and the verb of the sentence. In the SL text, the subject and the object are in the right place with the verb 'had suddenly caught', but the object of the sentence switches into the subject of the sentence in the TL text with the verb tertangkap oleh in the TL text. It means that the active sentence changes into the passive one in the TL text. However, the TL has a different standardization to equalize the SL text. For the other examples, the explanation of them is similar to the data that has been explained above.

\section{b) Class shift}

In this type of shifting, there are 5 data that is provided as a class shift. The researcher will explain three examples that represent the data of class shifts which are categorized into three types.

- Verb to noun

This category shows the shifting of class words from a verb into a noun.

TABLE V. THE EXAMPLE OF VerB TO NOUN

\begin{tabular}{|l|l|}
\hline \multicolumn{1}{|c|}{ Verb } & \multicolumn{1}{c|}{ Noun } \\
\hline $\begin{array}{l}\text { (7a) 'Man is the only } \\
\text { creature that } \\
\text { consumes without } \\
\text { producing ... }\end{array}$ & $\begin{array}{l}\text { (7b) Manusia adalah satu-satunya } \\
\text { makhluk di atas jagad ini yang } \\
\text { bisanya Cuma jadi konsumen, tapi } \\
\text { bukan produsen ... }\end{array}$ \\
\hline
\end{tabular}

This translation shift occurs in the class of the sentence that changes from the SL text into the TL text. For the examples above, the word 'consumes' and 'producing' in the SL text changes into konsumen and produsen. In the SL text, the word 'consumes' has the suffix $-\mathrm{s}$ that indicates the verb of the simple present tense. It expresses the opinion of the animals and shows what the man does on the farm. On the other hand, the word konsumen is a noun in the TL text which shows the term of the 'Man' itself, so that there is a changing the word-class from a verb into a noun. Catford [6] said that this shifting occurs when "the translation equivalent of an SL item is a member of a different class form the TL item.”

- Adjective to noun

This category shows the shifting of class words from an adjective into a noun.

TABLE VI. THE EXAMPLE OF ADJECTIVE TO NOUN

\begin{tabular}{|l|l|}
\hline \multicolumn{1}{|c|}{ Adjective } & \multicolumn{1}{|c|}{ Noun } \\
\hline $\begin{array}{l}\text { (8a) Sometimes the work was } \\
\text { hard; ... }\end{array}$ & $\begin{array}{l}\text { (8b) Kadangkala, kerja memang } \\
\text { menghadapi kesulitan. }\end{array}$ \\
\hline
\end{tabular}

In the other example, the word 'hard' as an adjective in the SL text changes into kesulitan as a noun in the TL test. It shows that there is a class shift from adjective to noun. The word kesulitan comes from the adjective sulit which gets the prefix $k e$ - and the suffix -an. This formation makes the word changing into a noun that has a meaning 'in a situation'.

- $\quad$ Noun to verb

This category shows the shifting of words from a noun into a verb.

TABLE VII. THE EXAMPLE OF ADJECTIVE TO NOUN

\begin{tabular}{|l|l|}
\hline Adjective & Noun \\
\hline $\begin{array}{c}\text { (9a) There was no wastage } \\
\text { whatever; ... }\end{array}$ & $\begin{array}{c}\text { (9b) Dan 4aka da yang hilang } \\
\text { dikorup atau dicolong. }\end{array}$ \\
\hline
\end{tabular}

In sentence (9a), the word 'wastage' as a noun in the SL text changes as a passive verb in the TL text. The word dikorup and dicolong in a sentence (9b) actually have the same meaning dicuriin Indonesian's culture. In this case, the translator uses common words that usually said by Indonesian people to be easier understood by the reader. It also has the prefix $d i$ - that indicates as the passive verb. However, this shifting common occurs when the translators want to emphasize the sentence.

\section{c) Unit Shift}

This study found 18 data that is included as a unit shift. The researcher will explain three examples that are divided into four categories.

\section{- Word to Sentence}

In this category, the shifting occurs from the low unit, word into the highest unit, sentence. This changing is used to emphasize the message of the SL text.
TABLE VIII. THE EXAMPLE OF WORD TO SENTENCE

\begin{tabular}{|c|c|}
\hline Word & Sentence \\
\hline
\end{tabular}




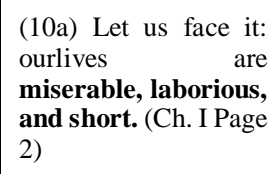

This translation shift occurs to get the translation equivalent by changing the rank of the TL text. The word 'miserable', 'laborious', and 'short' are included as an adjective in the SL text while in the TL text, those words changing into sentences that explained the subject of a sentence in the SL text. In this case, the unit of the sentence levels up from the word into a sentence. This shifting is suitable because it can give a stressed to that word.

TABLE IX. SHIFTING FROM A WORD INTO A SENTENCE

Miserable
Sedih/menyedihkan
paborious
Susah/melelahkan
Short $\begin{gathered}\text { Hidup kita ini } \\ \text { sebenarnya menyedihkan. } \\ \text { Pendek/singkat }\end{gathered}$

- Word to phrase

In this category, the shifting occurs from the low unit, word into phrase unit. Like the example below.

TABLE X. THE EXAMPLE OF WORD TO PHRASE

\begin{tabular}{|l|l|}
\hline \multicolumn{1}{|c|}{ Word } & \multicolumn{1}{|c|}{ Phrase } \\
\hline $\begin{array}{l}\text { (11a) Even so, it was found } \\
\text { necessaryto leave certain tasks } \\
\text { undone. (Ch. VI Page 24) }\end{array}$ & $\begin{array}{l}\text { (11b) Kendati begitu, ada beberapa } \\
\text { pekerjaan yang tak terselesaikan. }\end{array}$ \\
\hline
\end{tabular}

In the SL text, 'undone' is used to show the work that has not done yet. Therefore, in the TL text, that word changes into phrase tak terselesaikan that purposes to equalize the meaning of the SL text.

- $\quad$ Phrase to sentence

This category shows the shifting from phrase unit into a sentence unit. This shifting occurs by separating some 'phrase' to make a new sentence that is more completed and clearly.

TABLE XI. THE EXAMPLE OF PHRASE TO SENTENCE

\begin{tabular}{|c|c|}
\hline Phrase & Sentence \\
\hline $\begin{array}{l}\text { (12a) . . and which stood } \\
\text { beyond the kitchen. (Ch. IX } \\
\text { Page } 44)\end{array}$ & $\begin{array}{l}\text { (12b)Ruang itu terletak di belakang } \\
\text { dapur. }\end{array}$ \\
\hline
\end{tabular}

The phrase in a sentence (11a) does not have the subject and be replaced by the word 'which'. In the TL text, that phrase is separated from the sentence and makes the sentence itself. The word 'which' becomes Ruang itu indicates the place in the big barn. In this case, the phrase changes into a sentence to make it clear the meaning of the text. However, this shifting tries to get the ease of reading and make it clear the message of the text for the reader so that there is no misunderstood with the text.
- $\quad$ Sentence to phrase

This category shows the shifting from sentence unit into a phrase unit. This shifting occurs by combining two sentences and reducing some unimportant words to be a phrase.

TABLE XII. THE EXAMPLE OF SENTENCE TO PHRASE

\begin{tabular}{|c|c|}
\hline Sentence & Phrase \\
\hline $\begin{array}{c}\text { (13a) It is summed up } \\
\text { in a single word - Man. (Ch. } \\
\text { I Page 2) }\end{array}$ & $\begin{array}{c}\text { (13b) Dengan satu kata ringkas, } \\
\text { sebab musabab kesengsaraan bangsa } \\
\text { binatang disebabkan oleh manusia. }\end{array}$ \\
\hline
\end{tabular}

In the example above, a sentence of SL text changes into a phrase by reducing some words and makes it the adverbial words. This example shows that the shifting can happen from sentence into a phrase that purposes to make it shorten by using some easy words and easier to understand.

\section{CONCLUSION}

The finding out of the technique of translation above reveals the strategy or the way to make a Nababan, 2003. Teori Menerjemah BS, Yogyakarta. Percetakan Pelajar decision of a translator. The techniques of translation are used to send messages of the source text into the target text.

\section{REFERENCES}

[1] Aukerman, R. C., Reading in the Secondary School Classroom. McGraw-Hill, 1972

[2] Bailin, A., \& Grafstein, A., Readability: Text and Context. Retrieved from https://doi.org/10.1057/9781137388773, 2016

[3] Molina, Albir dan Amparo Hurtado, Translation techniques revised : a dynamic and functionalist approach. Dalam meta : Translation's journal XLVII, 4, 2004.

[4] Brislin, R. W., Translation: Application and research. New York : Gardner Press Inc, 1976.

[5] Bryman, A., \& Bell, E., Business Research Methods , $3^{\text {rd }}$ ed, Oxford University Press Inc, 2011.

[6] Catford, J. C., Language and Language Learning a Linguistic Theory of Translation. 110, 1965.

[7] Suryawinata, Z., \& Hariyanto, S., Translation : Bahasan Teori \& Penuntun Praktis Menerjemahkan. Media Nusa Creative, 2016.

[8] Fraenkel, J. R., \& Wallen, N. E., How to Design and Evaluate Research in Education, $7^{\text {th }}$ ed, Beth Maija, 2009.

[9] Newmark, P., A Textbook of Translation. Pearson Education, 1998.

[10] Sinha, M., Sharma, S., Dasgupta, T., \& Basu, A., New Readability Measures for Bangla and Hindi Texts, (December)1141-1150, 2012.

[11] Orwell, G., Animal Farm. Retrieved from https://doi.org/10.1016/S0262 4079(11)62978-3, 1945

[12] Chesterman, A. Memes of Translation (Vol. 22). Retrieved from https://doi.org/10.1075/btl.22, 1997.

[13] Newmark, P., A Textbook of Translation. Pearson Education, 1998.

[14] Baker, M., Routledge Encyclopedia of Translation Studies. London: Routledge, 1998.

[15] Catherine Marshall \& Gretchen B. Rossman, "Designing qualitative research," Qualitative Social Research, 9(3), Art. 13, retrieved from http://nbn-resolving.de/urn:nbn:de:0114-fqs0803137, 2006.

[16] Nababan, Teori Menerjemah BS.Yogyakarta: Percetakan Pelajar, 2003.

[17] Munday, J., Introducing Translation Studies: Theories and Applications. London : Routledge, 2001. 